\title{
Manajemen sumber daya manusia dengan waktu tunggu pasien di pelayanan farmasi Rumah Sakit X
}

\author{
Nancy Desrina Pasaribu*, Mafe Robbi Simanjuntak, Eva Ellya Sibagariang \\ Fakultas Kesehatan Masyarakat Universitas Prima Indonesia \\ *Korespondensi: nancydesrina4@gmail.com \\ DOI: doi.org/10.1616/jpms.v2i2.973 \\ (C) 2020 JPMS. All rights reserved
}

\begin{abstract}
Abstrak
Pelayanan farmasi adalah salah satu pelayanan kesehatan yang mendukung proses kegiatan penyembuhan pasien dalam proses pengobatannya yang dapat menjadi indikator mutu pelayanan kesehatan. Berdasarkan survei awal yang dilakukan di Unit Farmasi Rumah Sakit X masih banyak ditemui pasien yang menunggu obat lebih 1 jam. Tujuan penelitian ini untuk mengetahui hubungan manajemen sumber daya manusia dengan waktu tunggu pasien di pelayanan farmasi Rumah Sakit X. Jenis penelitian ini adalah deskriptif analitik dengan rancangan penelitian ini menggunakan rancangan penelitian cross-sectional. Jumlah sampel dalam penelitian ini adalah sebanyak 100 orang dengan teknik pengambilan random sampling. Hasil penelitian menyimpulkan adanya hubungan kualitas SDM $(0,000)$ dan kepuasan $(0,034)$ dengan waktu tunggu pasien di pelayanan farmasi Rumah Sakit $X$. Sedangkan tata letak obat tidak berhubungan dengan waktu tunggu pasien.
\end{abstract}

Kata kunci: Waktu tunggu, kepuasan, kualitas sumber daya manusia

\begin{abstract}
Pharmacy service is one of the health services that supports the process of patient healing activities in the treatment process which can be an indicator of the quality of health services. Based on the initial survey conducted at Hospital X's Pharmacy Unit, there were still many patients who waited for the drug for more than 1 hour. The purpose of this study was to determine the relationship between human resource management and patient waiting time at the $X$ Hospital pharmacy service. The type of this research was descriptive analytic with the design of this study using a cross-sectional research design. The number of samples in this study were 100 people with a random sampling technique. The results of the study concluded that there was a relationship between human resource quality $(0,000)$ and satisfaction (0.034) with patient waiting time at $X$ Hospital pharmacy service. Meanwhile, the drug layout was not related to patient waiting time.
\end{abstract}

Key words: Waiting time, satisfaction, quality of human resources

\section{Pendahuluan}

Rumah sakit merupakan salah satu sarana dalam upaya kesehatan yang menyelenggarakan kegiatan pelayanan kesehatan. Kegiatan pelayanan kesehatan di rumah sakit yaitu pelayanan rawat jalan, pelayanan rawat inap dan pelayanan gawat darurat yang mencakup pelayanan medik dan penunjang medik, salah satu yang mempunyai peranan penting adalah unit kefarmasian. Intalasi farmasi ini merupakan yang sangat penting di sektor rumah sakit. Rumah sakit akan kesulitan melakukan kegiatan apa bila di rumah sakit tidak tersedia obat.intalasi farmasi mempunyai pengaruh yang besar terhadap rumah sakit dan berbagai organisasi pelayanan kesehatan lainnya. ${ }^{1}$

Pelayanan kefarmasian harus dilakukan oleh apoteker dan tenaga teknis kefarmasian. Tenaga teknis kefarmasian yang melakukan pelayanan kefarmasian harus di bawah supervisi apoteker. Apoteker dan tenaga teknis kefarmasian harus memenuhi persyaratan administrasi seperti yang telah ditetapkan dalam peraturan perundang-undangan yang berlaku. ${ }^{2}$

Waktu tunggu pelayanan obat jadi adalah tegangan waktu mulai pasien menyerahkan resep hingga menerima obat jadi dengan standar minimal yang ditetapkan kementerian kesehatan adalah $\leq 30$ menit, waktu tunggu pelayanan obat racikan adalah tenggangan waktu mulai pasien menyerahkan resep hingga menerima obat racikan yaitu $\geq 60$ menit. ${ }^{3}$

Penelitian Margiluruswati (2017) menemukan bahwa faktor yang mengakibatkan se- 
makin lamanya pelayanan resep yaitu terdapat pada proses etiket dengan rata-rata 3 menit 34 detik dengan proses etiket tercepat 47 detik dan proses etiket terlama 12 menit. Waktu yang diperlukan dalam proses etiket dapat semakin lama dikarenakan petugas etiket harus menuliskan aturan pakai pada obat sesuai dengan resep pengisian pada KCO (Kartu Catat Obat) pasien meliputi: identitas pasien (nama pasien, dan nomor rekam medis), tanggal pengambilan obat, asal poliklinik, dokter yang melayani, resep obat, tanggal kembali periksa, atau tanggal ke laboratorium. Waktu tunggu pelayanan resep non racikan yang juga belum sepenuhnya sesuai dengan standar juga disebabkan juga oleh waktu jeda dari proses verifikasi ke proses entri data, yang mempunyai rata-rata waktu tunggu 35 menit 58 detik dengan waktu jeda tercepat 1 menit dan jeda terlama 1 jam 22 menit. Waktu jeda dari proses verifikasi ke proses entri data yang lama terjadi karena pengerjaan dari proses verifikasi lebih cepat daripada proses entri data. Adapun waktu jeda yang lain yang menjadi faktor semakin lamanya pelayanan resep non racikan yaitu, waktu jeda dari jeda pengambilan obat ke proses etiket, di mana pada jeda tersebut mempunyai waktu nilai maksimal jeda terlama dibanding dengan nilai maksimal pada proses maupun jeda di pelayanan resep non racikan. Sebab dari waktu jeda yang menjadi semakin lama dikarenakan kurang disiplinnya petugas dalam manajemen urutan nomor resep. Untuk waktu tunggu pelayanan resep racikan yang memiliki ratarata waktu tunggu 1 jam 02 menit 32 detik. Adapun dalam tahap pelayanan resep racikan yang memerlukan waktu paling lama yang pertama adalah pada tahap proses peracikan. Proses peracikan yang memiliki rata-rata pelayanan selama 7 menit 57 detik. Faktor penyebab proses peracikan menjadi proses yang paling lama karena peralatan penunjang yang digunakan saat memasukan obat yang telah diracik ke dalam kapsul meenggunakan alat yang sederhana. Tahap pelayanan resep yang menjadi penyebab lamanya waktu tunggu pelayanan resep racikan yang kedua adalah tahap jeda dari verifikasi ke entri data, yang mana pada tahap ini juga menjadi tahap jeda paling lama di pelayanan resep non racikan. Rata-rata jeda verifikasi ke entri data adalah 23 menit 48 detik, dengan waktu jeda tercepat 30 detik dan waktu jeda terlama 1 jam 07 detik. $^{4}$

Ketidaksesuaian waktu tunggu pelayanan resep dengan standar yang ada mengakibatkan waktu yang dibutuhkan oleh pasien untuk mendapatkan obatnya menjadi semakin lama. Hal tersebut dapat mengakibatkan ketidakpuasan pasien dan dapat menurunkan mutu pada pelayanan. Jika tidak dilakukan evaluasi mengenai perbaikan kualitas mutu pelayanan yang sesuai dengan target yang ditetapkan dapat menurunkan mutu dan citra rumah sakit.

Penelitian ini bertujuan untuk mengetahui hubungan manajemen sumber daya manusia dengan waktu tunggu pasien di pelayanan farmasi Rumah Sakit X.

\section{Metode Penelitian}

Penelitian dilaksanakan di Rumah Sakit X dengan populasi penelitian sebanyak 100 orang. Jenis penelitian ini adalah deskriptif analitik dengan rancangan penelitian menggunakan rancangan penelitian cross-sectional. Sampel diambil dengan teknik simple random sampling. Hasil penelitian diuji dengan menggunakan Chi Square dengan derajat kepercayaan $95 \%(\alpha=0,05)$.

\section{Hasil dan Pembahasan}

Data umum responden (lihat pada Tabel 1) berisi mengenai identitas responden seperti umur dan jenis kelamin. Mayoritas responden berumur 61-70 tahun sebanyak 29 orang (15\%) dan responden berumur paling sedikit pada rentang 15-20 tahun yaitu sebanyak 5 orang (5\%). Responden yang berjenis kelamin perempuan sebanyak 61 orang (61\%) dan minoritas jenis kelamin laki-laki sebanyak 39 orang (39\%). Sedangkan responden dengan kualitas SDM yang tidak baik yaitu sebanyak 63 orang $(63 \%)$ dan kualitas SDM baik sebanyak 37 orang $(37 \%)$.

Responden yang memiliki tata letak obat yang baik sebanyak 99 orang (99\%) dan responden dengan tata letak obat yang tidak baik sebanyak 1 (1\%). Mayoritas responden yang memiliki tingkat kepuasan rendah sebanyak 61 orang (61\%) dan responden dengan tingkat kepuasan yang tinggi sebanyak 39 orang (39\%). Sedangkan responden yang menyatakan waktu tunggu yang lama sebanyak 
67 orang $(67 \%)$ dan waktu tunggu yang cepat sebanyak 33 orang (33\%).

Tabel 1. Karakteristik responden

\begin{tabular}{|c|c|c|}
\hline & Jumlah (n) & Persentase (\%) \\
\hline \multicolumn{3}{|l|}{ Jenis Kelamin } \\
\hline Laki-Laki & 39 & 40 \\
\hline Perempuan & 61 & 60 \\
\hline \multicolumn{3}{|l|}{ Umur } \\
\hline $15-20$ & 5 & 5 \\
\hline $21-30$ & 13 & 13 \\
\hline $31-40$ & 14 & 14 \\
\hline $41-50$ & 14 & 14 \\
\hline $51-60$ & 12 & 12 \\
\hline $61-70$ & 29 & 29 \\
\hline $71-80$ & 13 & 13 \\
\hline \multicolumn{3}{|l|}{ Kualitas SDM } \\
\hline Kurang & 37 & 37 \\
\hline Baik & 63 & 63 \\
\hline \multicolumn{3}{|c|}{ Tata Letak Obat } \\
\hline Baik & 99 & 99 \\
\hline Tidak baik & 1 & 1 \\
\hline \multicolumn{3}{|c|}{ Kepuasan Pasien } \\
\hline Puas & 39 & 39 \\
\hline Tidak Puas & 61 & 61 \\
\hline \multicolumn{3}{|l|}{ Waktu Tunggu } \\
\hline Lama & 67 & 67 \\
\hline Cepat & 33 & 33 \\
\hline Total & 92 & 100,0 \\
\hline
\end{tabular}

Demikian juga hasil uji statistik (lihat Tabel 2) pada variabel kualitas SDM terhadap waktu tunggu pasien, diperoleh hasil p-value 0,000. Artinya ada hubungan kualitas SDM dengan waktu tunggu pasien. Responden dengan kualitas SDM yang tidak baik dengan lama waktu tunggu pasien sebanyak 57 orang $(90 \%)$ dan kualitas SDM yang baik dengan lama waktu tunggu pasien sebanyak 10 orang (27\%). Hasil uji statistik pada variabel tata letak obat terhadap waktu tunggu pasien, diperoleh hasil $p$-value 0,152 . Artinya tidak ada hubungan tata letak obat dengan waktu tunggu pasien. Responden dengan tata letak obat yang baik dengan lama waktu tunggu pasien sebanyak 67 orang (67\%).

Tabel 2. Hasil uji Chi-Square

\begin{tabular}{|c|c|c|c|c|c|c|c|}
\hline \multirow{3}{*}{ Variabel } & \multicolumn{4}{|c|}{ Waktu Tunggu Pasien } & \multirow{2}{*}{\multicolumn{2}{|c|}{ Total }} & \multirow{3}{*}{$p$ value } \\
\hline & \multicolumn{2}{|c|}{ Lama } & \multicolumn{2}{|c|}{ Cepat } & & & \\
\hline & $\mathbf{N}$ & $\%$ & $\mathbf{N}$ & $\%$ & $\mathbf{N}$ & $\%$ & \\
\hline \multicolumn{8}{|l|}{ Kualitas SDM } \\
\hline Baik & 10 & 27 & 27 & 73 & 37 & 37 & 0,000 \\
\hline Tidak Baik & 57 & 90 & 6 & 10 & 63 & 63 & \\
\hline \multicolumn{8}{|l|}{ Tata Letak Obat } \\
\hline Baik & 67 & 67 & 32 & 32,3 & 99 & 99 & 0,152 \\
\hline Tidak Baik & - & - & 1 & 100 & 1 & 1 & \\
\hline \multicolumn{8}{|l|}{ Kepuasan } \\
\hline Baik & 31 & 79,5 & 8 & 20,5 & 39 & 39 & 0,034 \\
\hline Tidak baik & 36 & 59 & 25 & 41 & 61 & 61 & \\
\hline
\end{tabular}

Sedangkan hasil uji statistik pada variabel kepuasan terhadap waktu tunggu pasien, diperoleh $p$-value 0,034 . Artinya ada hubungan kepuasan dengan waktu tunggu pasien. Res- 
ponden dengan tingkat kepuasan yang tidak baik dengan lama waktu tunggu pasien sebanyak 36 orang (59\%) dan kepuasan yang baik dengan waktu tunggu lama sebanyak 31 orang $(79,5 \%)$.

\section{Pembahasan}

Hasil uji statistik pada variabel kualitas SDM menunjukkan ada hubungan antara kualitas SDM dengan waktu tunggu pasien. Penelitian yang dilakukan oleh Megawati dkk. (2015) menyatakan bahwa ada hubungan antara kualitas sumber daya manusia dengan waktu tunggu di pelayanan farmasi dengan $p$ value $0,01 .{ }^{5}$ Namun penelitian Kurniasih (2016) tentang Analisis Mutu Pelayanan Farmasi di Unit Rawat Jalan Rumah Sakit $X$ di Bogor menyimpulkan bahwa tidak adanya hubungan antara kualitas sumber daya manusia dengan waktu tunggu pasien karena pada aspek hasil, frekuensi kejadian potensi medication error masih tinggi. Di depo farmasi A potensi medication error sebanyak 209 dalam 158 resep sementara di depo farmasi $B$ sebanyak 74 kejadian dalam 115 resep. Angka keterjaringan resep belum maksimal, di depo farmasi A $64,1 \%$ sementara di depo farmasi B $54,2 \%$ survei kepuasan pasien menunjukan semua dimensi mutu pelayanan bernilai gap negative, gap terbesar ada dimensi responsiveness dengan nilai gap 0,5 di depo farmasi A 0,31\% dan di depo farmasi B. Presentasi belum memenuhi standar minimal yang ditetapkan pemerintah artinya mutu pelayanan yang di sajikan oleh interaksi farmasi RS PMI Bogor di depo farmasi rawat jalan belum bisa memenuhi harapan pasien sebagai pengguna jasa pelayanan farmasi. ${ }^{6}$

Hasil uji statistik pada variabel tata letak obat menunjukkan tidak ada hubungan antara tata letak obat dengan waktu tunggu pasien. Studi yang dilakukan oleh Jonrinaldi dkk. (2007) menyatakan adanya hubungan antara tata letak obat dengan waktu tunggu pasien karena pada dasarnya gudang farmasi menerapkan prinsip fifo (first in first out) dalam pengambilan obat, tetapi karena karyawan mengalami kesulitan dalam mencari barang di gudang, tata letaknya yang kacau dan belum terdapatnya informasi lokasi obat menyebabkan prinsip fifo ini tidak berjalan. Pengambilan yang tidak mengikuti aturan menyebabkan terdapatnya obat yang kadaluarsa. Berdasarkan data yang diperoleh dapat diketahui bahwa jumlah obat yang kadaluarsa pada tahun 2006 menyebabkan hilangnya dana sebesar Rp 17.335.717 yang merupakan total dari harga obat yang kadaluarsa. $^{7}$

Hasil uji chi square pada variabel kepuasan menunjukkan ada hubungan antara kepuasan pasien dengan waktu tunggu pasien. Penelitian yang dilakukan oleh Nurjanah (2016) menunjukkan bahwa waktu tunggu pelayanan resep merupakan waktu yang digunakan oleh karyawan apotek Kimia Farma BLU RSUP Prof. Dr. R.D. Kandou dalam menyelesaikan resep. Untuk meningkatkan kualitas pelayanan, apotek Kimia Farma BLU RSUP Prof. Dr. R.D Kandou melakukan berbagai kebijakan terutama dalam hal pelayanan obat atas resep dokter yang berkaitan dengan waktu tunggu pelayanan resep. Berdasarkan hasil penelitian menunjukan bahwa adanya hubungan antara waktu tunggu pelayanan resep dengan kepuasan pasien. Pelayanan resep yang lama akan menurunkan tingkat kepuasan dalam hal waktu tunggu pelayanan. Tetapi, pelayanan resep yang cepat akan meningkatkan kepuasan pasien dalam hal waktu tunggu pelayanan. Sehingga apotek akan mendapatkan pasien yang loyal karena kualitas pelayanan yang baik dalam hal waktu tunggu pelayanan yang cepat. ${ }^{8}$ Kastella (2019) menyatakan bahwa waktu tunggu secara parsial berpengaruh terhadap Kepuasan pasien di Instalasi Farmasi RS Bhayangkara Brimob. Nilai t hitung negatif, artinya berpengaruh negatif yaitu semakin meningkat penilaian tentang Waktu tunggu maka akan menurunkanKepuasan pasien. ${ }^{9}$

\section{Kesimpulan}

Penelitian ini menyimpulkan adanya hubungan kualitas $\operatorname{SDM}(0,000)$ dan kepuasan $(0,034)$ dengan waktu tunggu pasien di pelayanan farmasi Rumah Sakit X. Sedangkan tata letak obat tidak berhubungan dengan waktu tunggu pasien.

\section{Referensi}

1. Kementerian Kesehatan. Keputusan Menteri. Kesehatan Nomor 1204/MENKES/SK/X/2004 Tentang Persyaratan Kesehatan Lingkungan Rumah Sakit. Jakarta. 2004. 
2. Kementerian Kesehatan. Peraturan Menteri Kesehatan Republik Indonesia Nomor 58 Tahun 2014 Tentang Standar Pelayanan Kefarmasian di Rumah Sakit. Jakarta. 2014.

3. Kementerian Kesehatan. Keputusan Menteri Kesehatan Republik Indonesia No.129/Menkes/SK/II/2008 Tentang Standar Pelayanan Minimal Rumah Sakit. Jakarta. 2008.

4. Margiluruswati P, Irmawati LI. Analisis Ketepatan Waktu Tunggu Pelayanan Resep Pasien JKN Dengan Standar Pelayaan Minimal Rumah Sakit 2017 (Studi di UPF Rawat Jalan RSUD Bhakti Dharma Husada). Jurnal Manajemen Kesehatan Yayasan RS. Dr. Soetomo, Vol.3 No.1 p.115 -126: 2017

5. Megawati, Hariyanto T, Rachmi AT. Hubungan Dimensi Mutu Pelayanan Farmasi Rawat Jalan dengan Kepuasan Pasien di RS Baptis Batu: Peran Kepesertaan Asuransi. Jurnal Aplikasi Manajemen Vol.14 No.1: 2016.

6. Kurniasih FD, Amalia L, Anggraini Y. Analisis Mutu Pelayanan Farmasi di Unit Rawat Jalan Rumah Sakit X di Bogor. Social Clinical Pharmacy Indonesia Journal Vol.1 No.1: 2016.

7. Jonrinaldi, Wirdianto $E$, Nirmala $M$. Perancangan Tata Letak dan Sistem Informasi Gudang Farmasi dan Perbekalan Kesehatan di Kota $X$. Jurnal Optimasi Sistem Industri Vol.7 No.1 p.27-37: 2007.

8. Nurjanah I, Maramis FRR, Engkeng S. Hubungan Antara Waktu Tunggu Pelayanan Resep Dengan Kepuasan Pasien di Apotek Pelengkap Kimia Farma BLU Prof. Dr. R.D. Kandou Manado. Pharmacon Vol.5 No.1: 2016.

9. Kastella NAF. Evaluasi Pelayanan Instalasi Farmasi Terhadap Waktu Tunggu Obat dan Kepuasan Pelanggan Ditinjau Dari Kecepatan Pelayanan Resep di Rumah Sakit Bhayangkara Brimob. Jurnal Manajemen dan Administrasi Rumah Sakit Vol.3 No.1: 2019. 